\title{
Ixodes ricinus abundance and its infection with the tick-borne pathogens in urban and suburban areas of Eastern Slovakia
}

Lucia Pangrácová1, Markéta Derdáková1,2*, Ladislav Pekárik², Ivana Hviščová1, Bronislava Víchová ', Michal Stanko ${ }^{1,2}$, Helena Hlavatá ${ }^{3}$ and Branislav Pet'ko ${ }^{1}$

\begin{abstract}
Background: Raising abundance of ticks and tick-borne diseases in Europe is the result of multiple factors including climate changes and human activities. Herein, we investigated the presence and seasonal activity of Ixodes ricinus ticks from 10 urban and suburban sites in two different geographical areas of southeastern and northeastern Slovakia during 2008-2010. Our aim was to study the abundance of ticks in correlation with the environmental factors and their infection with Borrelia burgdorferi sensu lato, Anaplasma phagocytophilum and Neoehrlichia mikurensis.
\end{abstract}

Methods: Questing I. ricinus ticks were collected from ten urban and suburban sites in Eastern Slovakia. A total of 670 ticks were further analysed for the presence of B. burgdorferi s.l., A. phagocytophilum and N. mikurensis by molecular methods. Tick site and environmental relations were analysed using General Linear Models (LM). The differences between the number of Lyme borreliosis cases between the Košice and Bardejov regions during a ten-year period were tested by Wilcoxon matched pairs test.

Results: In total, 2921 (1913 nymphs, 1008 adults) I. ricinus ticks were collected from 10 study sites during the main questing season. Tick activity and relative abundance differed between locations and months. Temperature and humidity were the main factors affecting the tick abundance and questing activity. Out of 670 examined ticks, $10.15 \%$ were infected with spirochetes from B. burgdorferi s.l. complex (represented by B. afzelii, B. garinii, B. valaisiana and B. burgdorferi s.s.), $2.69 \%$ with the A. phagocytophilum and $2.39 \%$ with N. mikurensis. The number of Lyme borreliosis cases per 100,000 inhabitants in the Bardejov region was significantly higher than in the Košice region.

Conclusions: Our data indicate that the risk of infection with tick-borne pathogens in Eastern Slovakia is common since $15.2 \%$ of ticks were infected at least with one of the tested microorganisms. Even though the abundance of ticks was affected by the microclimatic conditions and the prevalence of pathogens differed between the habitats, the infection risk for humans is also affected by human activities leading to an increased contact with infected ticks.

Keywords: Ixodes ricinus, Borrelia burgdorferi sensu lato, Anaplasma phagocytophilum, Neoehrlichia mikurensis, PCR-RFLP, Lyme borreliosis, Anaplasmosis

\footnotetext{
* Correspondence: marketa.derdakova@gmail.com

${ }^{1}$ Institute of Parasitology SAS, Košice, Hlinkova 3040 01, Slovakia

${ }^{2}$ Institute of Zoology SAS, Bratislava, Dúbravská cesta 9845 06, Slovakia

Full list of author information is available at the end of the article
} 


\section{Background}

In Europe, the changing climate and human activities in the environment have caused the changes in tick abundance together with the spread of ticks into the northern regions, urban and suburban areas as well as higher altitudes. This phenomenon is associated with the spread of tick-borne pathogens and new foci in the areas, previously free of the tick-borne diseases, which have been established [1-5]. Abiotic factors of the microclimate such as temperature, humidity, saturation or vapour pressure deficit and wind influence the survival of ticks and their questing behaviour in the habitat [6-8]. Structure of the habitat and the host availability for ticks also largely influence their phenology. The epidemiologically most important tick in Europe, Ixodes ricinus, transmits viral, bacterial as well as protozoan pathogens to humans and animals. The most commonly occurring and the most serious bacterial agents transmitted by this tick in Europe are spirochetes from the Borrelia burgdorferi sensu lato complex. They are causative agents of Lyme borreliosis, the multisystemic disorder that is maintained in natural foci in a wide spectrum of vertebrate reservoir hosts [9]. Currently 19 different genospecies belong to this complex out of which at least 9 are present in Europe [10]. The specific associations of different genospecies with the reservoir hosts as well as clinical symptomatics have been assigned [11], however, this association is not strict and differences have been observed [12]. The occurrence of Lyme borreliosis has been reported from various habitats of Europe between 35 to $60^{\circ} \mathrm{N}$ with the focal distribution even within small countries and thus following the occurrence of ticks [13]. The highest yearly incidence is in Central Europe, namely in Austria and Slovenia, with 130 and 136 cases per 100000 inhabitants [13]. Another bacterial zoonotic disease, transmitted by I. ricinus, is granulocytic anaplasmosis caused by Anaplasma phagocytophilum. Anaplasmosis is the common tick-borne bacterial disease of domestic animals often causing tick-borne fever in ruminants on pastures [14]. In Europe, human cases are less common than in US $[15,16]$. The prevalence of $A$. phagocytophilum in questing ticks in Slovakia varies from 1.1 to $7.8 \%$ [17]. Neoehrlichia mikurensis is another tick-borne pathogen from the family Anaplasmataceae that attracts the attention of public health professionals in Europe. It was detected in questing ticks throughout Europe [18-21]. Rodents have been proposed as potential reservoir hosts since it was detected in blood and endothelial cells of their spleens and livers [22,23]. Recently its pathogenicity in humans was reported as it was detected in patients with septicaemia and immunosuppressed patients [24-27]. Moreover, it was detected in a chronically neutropenic dog from Germany [28].
The main aim of this study was to investigate the abundance and activity of $I$. ricinus ticks in urban and suburban areas of two cities in Eastern Slovakia in relation to the tick habitat and environmental conditions. The infection rates with the three most important tick-borne bacterial pathogens (B. burgdoferi s.l., A. phagocytophilum and $N$. mikurensis) were investigated as well. Furthermore, the occurrence of ticks and the presence of Borrelia were analysed in conjunction with the incidence of human cases reported to the State Health Institute during the last 10 years from both studied regions.

\section{Methods}

\section{Collection of ticks}

I. ricinus ticks were collected from ten sites (Table 1). Five model sites were selected in suburban forest and urban parks of Košice - a large urban agglomeration in southeastern Slovakia with previously known high occurrence of ticks and its infection with Borrelia as well as Anaplasma [29] and five sites were selected in Bardejov- a small town in northeastern Slovakia, with a cooler climate and very few data on presence of ticks. Ticks were collected from April till October 2008 in Bardejov area and from April till October 2010 in Košice area. Each collection was conducted using white corduroy flags for one or more hours of flagging to cover various types of land cover in each studied site. Relative abundance of ticks was calculated per one hour of flagging at each collection site and collection. After the collection, ticks were immediately immersed in tubes with $70 \%$ ethanol until the DNA was extracted. Ticks were further analysed for the presence of B. burgdorferi s. 1., A. phagocytophilum and N. mikurensis by molecular methods.

Saturation deficit was calculated according to Randolph et al. [6] and vapour pressure deficit was calculated following the approach of Li et al. [8]. Daily mean temperatures (Figure 1) and humidity values (Figure 2) were obtained from the Slovak Hydrometeorogical Institute in Košice from the nearest meteorogical stations $\left(48^{\circ} 67^{\prime} 06^{\prime \prime} \mathrm{N}\right.$; $\left.21^{\circ} 23^{\prime} 86^{\prime \prime} \mathrm{E}\right)$ at $229 \mathrm{~m}$ asl. in Košice and $\left(49^{\circ} 28^{\prime} 47^{\prime \prime} \mathrm{N}\right.$ a $\left.21^{\circ} 27^{\prime} 06^{\prime \prime} \mathrm{E}\right)$ at $305 \mathrm{~m}$ asl., in Bardejov.

\section{Statistical analysis}

Tick site and environmental relations were analysed using General Linear Models (LM). Basic models (with only fixed terms) were extended by random terms to deal with replications in the samples (repeated samples per sites). The response variable, tick relative abundance was $(\log +1)$ transformed to meet the requirements of normal error distribution. To assess the influence of selected variables on tick relative abundance, a model containing fixed independent terms, humidity, temperature, saturation deficit, vapour pressure deficit, elevation and biotope type and their quadratic forms and random 
Table 1 Description of tick collection sites

\begin{tabular}{|c|c|c|c|c|}
\hline Site & Geographical coordinates & Altitude & Site group* & Habitat type \\
\hline \multicolumn{5}{|l|}{ Northeast- Bardejov } \\
\hline 1 Smilno & $49^{\circ} 23^{\prime} 05^{\prime \prime} \mathrm{N} 21^{\circ} 20^{\prime} 58^{\prime \prime} \mathrm{E}$ & $425 \mathrm{~m}$ a.s.l. & C & -Birch-beech dry forest with hornbean shrubs \\
\hline 2 Tročany & $49^{\circ} 11^{\prime} 00^{\prime \prime} \mathrm{N} 21^{\circ} 20^{\prime} 00^{\prime \prime} \mathrm{E}$ & $345 \mathrm{~m}$ a.s.l. & B & $\begin{array}{l}\text {-Maple-oak forest with shruby humid vegetation around } \\
\text { pathways, close to the agricultural land }\end{array}$ \\
\hline 3 Raslavice & $49^{\circ} 09^{\prime} 00^{\prime \prime} \mathrm{N} 21^{\circ} 19^{\prime} 00^{\prime \prime} \mathrm{E}$ & $310 \mathrm{~m}$ a.s.l. & C & -Beech-oak dry forest, \\
\hline 4 Poštárka & $49^{\circ} 16^{\prime} 15^{\prime \prime} \mathrm{N} 21^{\circ} 17^{\prime} 03^{\prime \prime} \mathrm{E}$ & $332 \mathrm{~m}$ a.s.l. & B & $\begin{array}{l}\text {-Suburban beech forest with shruby vegetation, } \\
\text { in close proximity of cattle pastures }\end{array}$ \\
\hline 5 Bardejovské kúpele & $49^{\circ} 19^{\prime} 45^{\prime \prime} \mathrm{N} 21^{\circ} 16^{\prime} 15^{\prime \prime} \mathrm{E}$ & $283 \mathrm{~m}$ a.s.l. & C & -Urban beech-oak forest with park recultivation in some areas \\
\hline \multicolumn{5}{|l|}{ Southeast- Košice } \\
\hline 6 Adlerova & $48^{\circ} 74^{\prime} 00^{\prime \prime} \mathrm{N} 21^{\circ} 27^{\prime} 00^{\prime \prime} \mathrm{E}$ & $321 \mathrm{~m}$ a.s.l. & A & - Hornbeam suburban forest with shrubby vegetation \\
\hline 7 Anička & $48.74^{\prime} 00^{\prime \prime} \mathrm{N}, 21^{\circ} 25^{\prime} 00^{\prime \prime} \mathrm{E}$ & $200 \mathrm{~m}$ a.s.l. & C & - Urban park with large open areas without trees \\
\hline 8 Botanická záhrada & $48^{\circ} 44^{\prime} 49^{\prime \prime} \mathrm{N} 21^{\circ} 14^{\prime} 89^{\prime \prime} \mathrm{E}$ & $208 \mathrm{~m}$ a.s.l. & $\mathrm{B}$ & - Urban hornbeam-oak park with shrubs \\
\hline 9 Verejný cintorín & $48^{\circ} 69^{\prime} 00^{\prime \prime} \mathrm{N} 21^{\circ} 25^{\prime} 00^{\prime \prime} \mathrm{E}$ & $200 \mathrm{~m}$ a.s.l. & $\mathrm{B}$ & - Urban park at the cemetery \\
\hline 10 Jazero & $48^{\circ} 67^{\prime} 00^{\prime \prime} \mathrm{N} 21^{\circ} 31^{\prime} 00^{\prime \prime} \mathrm{E}$ & $192 \mathrm{~m}$ a.s.l. & $\mathrm{B}$ & - Urban hornbeam forest \\
\hline
\end{tabular}

*Habitats were classified into three groups according to the abundance of ticks (A-highest, B-lower, C-lowest).

term site identity was constructed. To select the best model, the least significant variables were removed from the model and new models were refitted. In the case that the fitting method based on restricted maximum likelihood (REML) did not allow model comparison, models were refitted by the maximum likelihood method. These procedures were repeated until the model changed significantly and until the Akaike information criterion (AIC) was decreasing. To assess the differences between sites in tick relative abundance a model containing fixed term site and random term month was constructed. If the results of contrasts (default treatment contrast) showed similar estimates and standard errors for particular sites, these sites were pooled and the model was refitted again. The best model selection followed the steps described above. All modelling procedures followed the approach described in Zuur et al. [30]. The differences between the number of Lyme borreliosis cases between the Košice and Bardejov regions during a ten-year period were tested by Wilcoxon matched pairs test. Data on Lyme borreliosis case incidence in studied

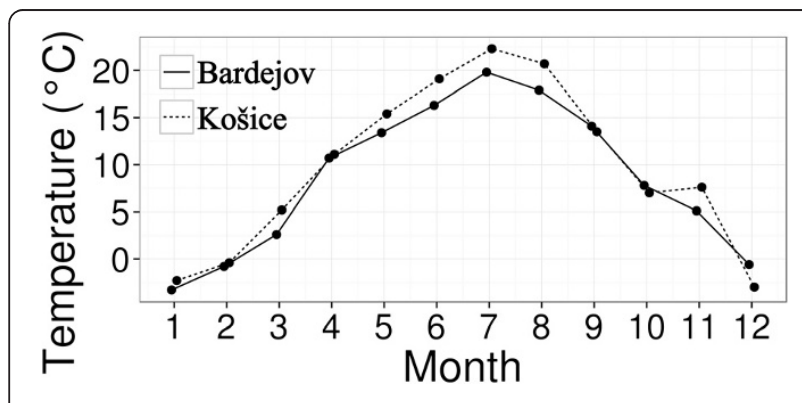

Figure 1 Mean monthly temperatures in Košice and Bardejov. regions (Košice and Bardejov) were obtained from the Epidemiological Information System of Slovakia [31]. Confidence intervals (CI) for infection rates were obtained by Exact Binomial test. All statistical analyses were performed in $\mathrm{R}$ statistical software environment [32] and R package nlme [33].

\section{Molecular identification of tick-borne pathogens}

Genomic DNA from each tick was isolated after its removal from ethanol and drying on filter paper by the method of alkaline-hydrolysis using $1.25 \%$ of ammonium solution, according to the previously described protocol [34]. Each tick was homogenized with a sterile pestle and negative extraction controls containing only ammonium solution were prepared for each set of DNA extraction to monitor the possible contamination. Extracted DNA from ticks was further analysed for the presence of $B$. burgdorferi s.l. complex by amplification of a $250 \mathrm{bp}$ long fragment of 5S-23S (rrfA-rrlB) rDNA intergenic spacer using primers IgsA (5'CGACCTTCTTCGCCTTAAAGC' 3) and IgsB (5'AGCTCTTATTCGCTGATGTA'3) [35].

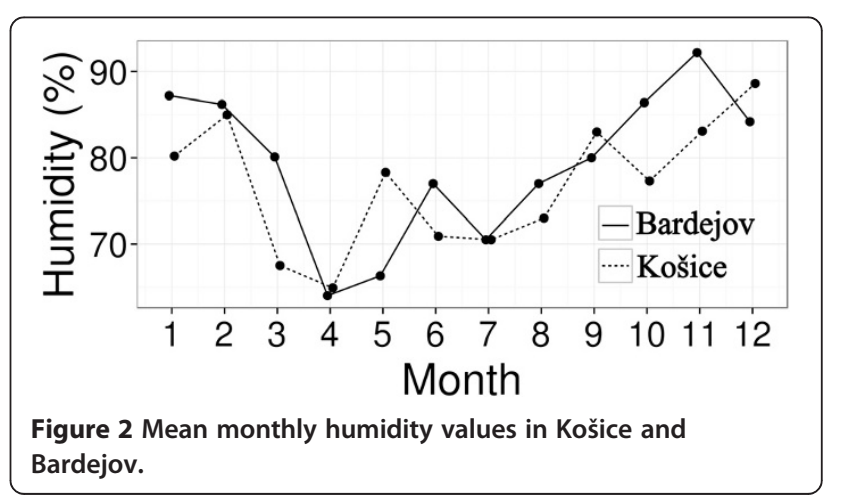




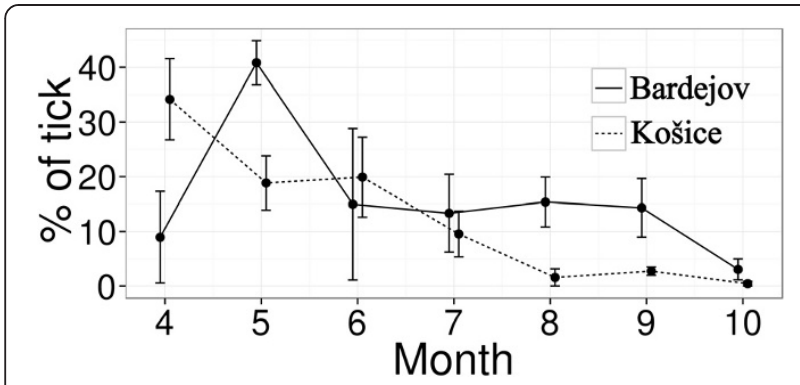

Figure 3 Mean tick proportion, tick proportion range during questing season at Košice (5 sites) and Bardejov (5 sites).

For the molecular detection of A. phagocytophilum, PCR amplification of a 849 bp long fragment of $m s p 4$ gene was used, with primers MAP4Ap5 (5'ATGAATTACAGAGA ATTGCTTGTAGG'3) and MSP4Ap3 (5'TTAATTGAA AGCAAA TCTTGCTCCTATG'3) [36]. To detect $N$. mikurensis a 560 bp long fragment of $16 \mathrm{~S}$ rRNA gene was amplified using IS58-594r (5'CTATCCTCTCTCGATCTC TAGT'3) and IS58-62f (5'GGAATAGCTGTTAGAAAT GAC'3) primers [22]. MasterTaq DNA polymerase kit (Eppendorf AG, Hamburg, Germany) was used for PCR amplifications. A total volume of $25 \mu \mathrm{l}$ of reaction mixture consisted of: $2.5 \mu$ template DNA (sample), $7.6 \mu \mathrm{l}$ of nuclease free water, $12.5 \mu \mathrm{l}$ of PCR Master mix, and $1.2 \mu \mathrm{l}$ of each primer $(10 \mathrm{pmole} / \mu \mathrm{l})$. Positive and negative controls were used in each PCR reaction. The PCR products were electrophoresed on 2\% agarose gels stained with GoldView Nucleic Acid Stain (Beijing SBS Genetech, Beijing, China). Amplified fragments were visualised in a transilluminator under UV light.

Table 2 A relative density (RD) of ticks per one hour of collection of total sampling at model sites, a percentage proportion of developmental stage and sex

\begin{tabular}{lllll}
\hline Site & $\begin{array}{l}\text { RD of } \\
\text { ticks }\end{array}$ & $\begin{array}{l}\% \text { of } \\
\text { nymphs }\end{array}$ & $\begin{array}{l}\% \text { of } \\
\text { females }\end{array}$ & $\begin{array}{l}\% \text { of } \\
\text { males }\end{array}$ \\
\hline
\end{tabular}

Northeast- Bardejov

$\begin{array}{lllll}1 \text { Smilno } & 2 & 56 & 44 & 0 \\ \text { 2 Tročany } & 15 & 59 & 21 & 20 \\ \text { 3 Raslavice } & 24 & 56 & 22 & 22 \\ \text { 4 Poštárka } & 12 & 76 & 14 & 10 \\ \text { 5 B. kúpele } & 6 & 73 & 5 & 22\end{array}$

Southeast- Košice

\begin{tabular}{lllll}
6 Adlerova & 138 & 73 & 12 & 15 \\
7 Anička & 2 & 14 & 29 & 57 \\
8 Botanická záhrada & 20 & 77 & 10 & 13 \\
9 Verejný cintorín & 16 & 14 & 36 & 50 \\
10 Jazero & 15 & 8 & 41 & 51 \\
\hline
\end{tabular}
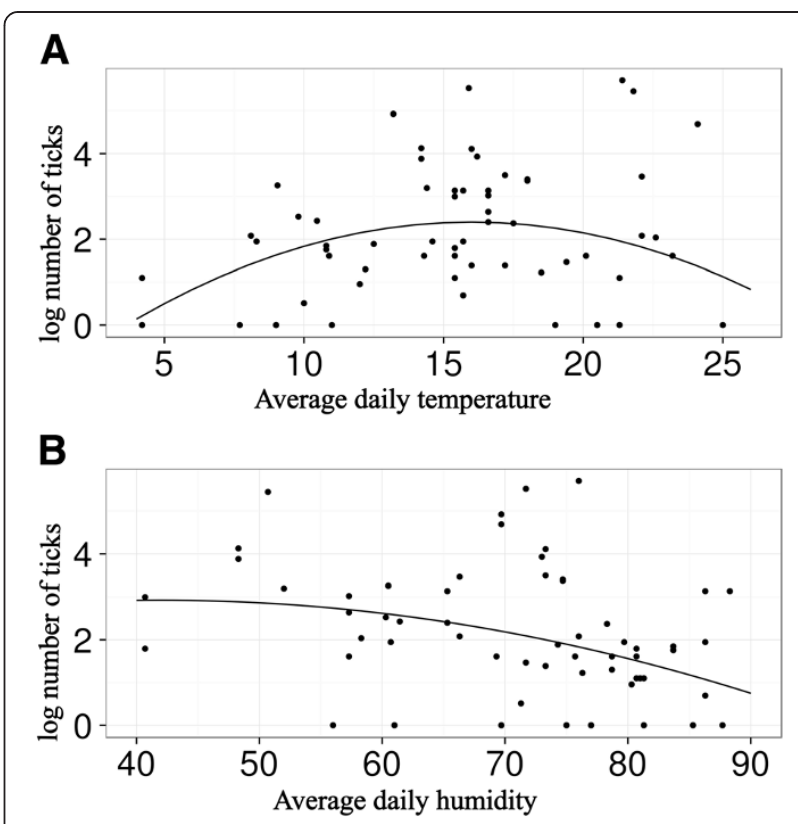

Figure 4 Graphical expression of the relation between average daily temperature (A), average relative daily humidity (B) and number of ticks based on the results of linear model.

In the case of Borrelia positive ticks, samples were further assigned to the different genospecies by RFLP method using Tru1 restriction endonuclease (Fermentas, Vilnius, Lithuania) as described before [35].

Selected positive PCR products of the $16 \mathrm{~S}$ rDNA fragment of $N$. mikurensis were purified by using a QIAquick PCR purification kit (Qiagen, Hilden, Germany) and sequenced in both directions with the same primers as for the PCR amplifications. Sequencing was performed at the University of Veterinary Medicine and Pharmacy in Košice; Department of Microbiology and Immunology. The complementary strands of each sequenced product were manually assembled. Sequences were compared to GenBank entries by Blast N2.2.13 [37]. The GenBank accession number for the nucleotide sequences of partial $16 \mathrm{~S}$ rDNA of $N$. mikurensis is JN378917.

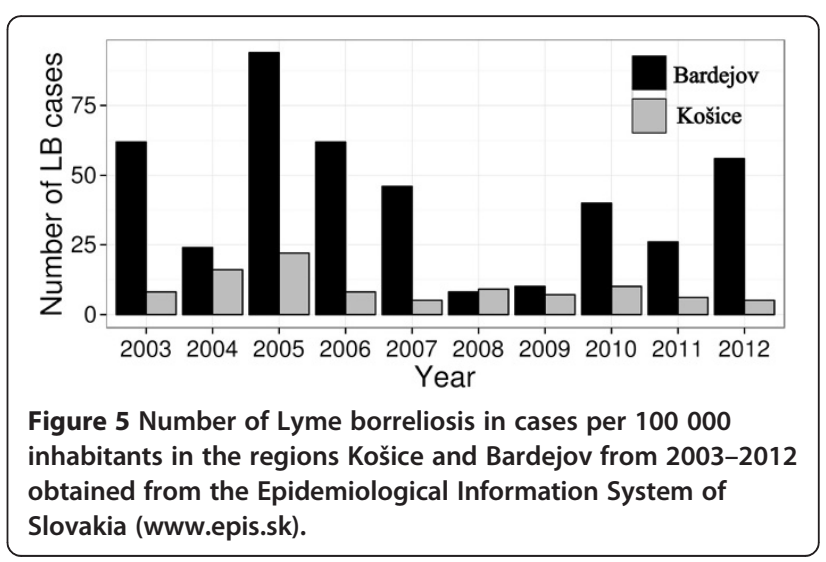




\section{Results}

In total 2921 (1913 nymphs, 1008 adults) I. ricinus ticks were collected from 10 study sites during the main questing season of ticks. Tick activity and relative abundance per one hour of sampling differed between locations and months (Figure 3, Table 2). The highest relative abundance was observed in a suburban broadleaf forest in Košice (site no. 6) from May to July (232 - 300 ticks per hour) and the peak was recorded in June (300 ticks per hour) with the unimodal pattern. The abundance of ticks in other collection sites in Košice that were represented by urban parks (sites 7-10) was significantly lower with a unimodal pattern as well. At three sites, represented by urban parks, adult ticks were more abundant than nymphs.

In the northeastern suburban forest habitat of Bardejov (site no. 2), seasonal activity of ticks also had a unimodal pattern with the peak in May (Figure 3).

The final model describing tick environmental relations consisted of two significant variables, humidity ( $\mathrm{F}$ value $13.29, \mathrm{p}<0.01$ ) and temperature ( $\mathrm{F}$ value 1.96 , $\mathrm{p}=0.17$ ) and temperature quadratic term ( $\mathrm{F}$ value 11.72 , $\mathrm{p}<0.01)$. The tick relative abundance was higher in temperatures between $15-20^{\circ} \mathrm{C}$ and tick relative abundance decreased at the humidity more than $80 \%$ (Figure 4 ). Saturation deficit, vapour pressure deficit, site elevation and biotope type were removed from the model in the modelling procedure. Removing these variables, model AIC decreased substantially (212.19 vs. 222.44) and this step was supported by model comparison (L-ratio 7.75, $\mathrm{p}=0.56$ ). The model describing tick site relation showed significant differences between sites (denDF 57, F-value 38.02, $\mathrm{p}<0.01$ ). After pooling the sites into three groups (A, B, C) (Table 1) the model AIC decreased substantially (202.09 vs. 210.91$)$ and this pooling was supported by model comparison ( $\mathrm{L}$ - ratio $2.55, \mathrm{p}=0.92$ ).

The number of Lyme borreliosis cases per 100000 inhabitants between the Košice and Bardejov regions were significantly different $(\mathrm{V}=1, \mathrm{p}<0.01)$ (Figure 5$)$, the number of cases in the latter region was higher (mean 42.8 vs. 9.60$)$.

In total 670 ticks were tested for the presence of pathogens (B. burgdorferi s.l., A. phagocytophilum and N. mikurensis (Table 3). 10.15\% (CI: 7.97-12.69) out of 670 examined ticks, were infected with spirochetes from B. burgdorferi s.l. complex. Except for one site (4), borreliae were detected at each location. RFLP analysis of positive samples revealed the presence of $B$. afzelii, $B$. garinii, B.valaisiana, B. burgdorferi sensu stricto and in one case mixed infection of B. garinii and B. valaisiana. The highest genetic variability of borreliae was observed in suburban forest in Košice (site 6). The mean infection rate for A. phagocytophilum was $2.69 \%$ (CI: 1.6-4.21) (Table 3 ). The occurrence of $A$. phagocytophilum was more patchy than was that for B. burgdorferi s.l., as it was detected only at 4 out of 10 sites. Sixteen ticks (2.39\%; CI: 1.37-3.85) were infected with N. mikurensis. It was present at each site of five localities in the northeast (Bardejov). In contrast, in the southeast (Košice), it was detected at two out of five sites only.

Table 3 Infection rate and $95 \%$ confidence interval $(\mathrm{CI})$ of $\mathbf{N}$. mikurensis, A. phagocytophilum and B. burgdorferi s.l. in I. ricinus ticks from sampling sites in Slovakia

\begin{tabular}{|c|c|c|c|c|c|c|c|c|c|c|}
\hline Site & $\begin{array}{c}\text { No. of } \\
\text { ticks tested }\end{array}$ & $\begin{array}{c}N . \\
\text { mikurensis }\end{array}$ & $\%$ & $\mathrm{Cl}$ & $\begin{array}{c}\text { A. } \\
\text { phagocytophilum }\end{array}$ & $\%$ & $\mathrm{Cl}$ & $\begin{array}{l}\text { B. burgdorferi } \\
\text { s.l. }\end{array}$ & $\%$ & $\mathrm{Cl}$ \\
\hline Northeast- Bardejov & 179 & 8 & 4.47 & $(1.95-8.62)$ & 3 & 1.68 & $(0.35-4.82)$ & 8 & 4.47 & $(1.95-8.62)$ \\
\hline 1 Smilno & 9 & 1 & 11.11 & $(0.28-48.25)$ & 0 & 0.00 & $(0.00-33.63)$ & 3 & 33.33 & (7.49-70.07) \\
\hline 2 Tročany & 31 & 2 & 6.45 & $(0.79-21.42)$ & 0 & 0.00 & $(0.00-11.22)$ & 3 & 9.68 & $(2.04-25.75)$ \\
\hline 3 Raslavice & 22 & 1 & 4.55 & $(0.12-22.84)$ & 1 & 4.55 & $(0.12-22.84)$ & 1 & 4.55 & $(0.12-22.84)$ \\
\hline 4 Poštárka & 75 & 3 & 4.00 & $(0.84-11.25)$ & 2 & 2.67 & $(0.32-9.30)$ & 0 & 0.00 & $(0.00-4.80)$ \\
\hline 5 B. kúpele & 42 & 1 & 2.38 & $(0.06-12.57)$ & 0 & 0.00 & $(0.00-8.41)$ & 1 & 2.38 & $(0.06-12.57)$ \\
\hline Southeast- Košice & 491 & 8 & 1.63 & $(0.71-3.19)$ & 15 & 3.05 & $(1.72-4.99)$ & 60 & 12.22 & $(9.46-15.45)$ \\
\hline 6 Adlerova & 261 & 5 & 1.92 & $(0.62-4.41)$ & 10 & 3.83 & $(1.85-6.93)$ & 47 & 18.01 & $(13.5-23.22)$ \\
\hline 7 Anička & 6 & 0 & 0.00 & $(0.00-45.93)$ & 0 & 0.00 & $(0.00-45.93)$ & 1 & 16.67 & $(0.42-64.12)$ \\
\hline 8 Botanical garden & 79 & 0 & 0.00 & $(0.00-4.56)$ & 0 & 0.00 & $(0.00-4.56)$ & 4 & 5.06 & $(1.40-12.46)$ \\
\hline 9 Verejný cintorín & 54 & 0 & 0.00 & $(0.00-6.60)$ & 0 & 0.00 & $(0.00-6.60)$ & 1 & 1.85 & $(0.04-9.89)$ \\
\hline 10 Jazero & 91 & 3 & 3.30 & $(0.69-9.33)$ & 5 & 5.49 & $(1.81-12.36)$ & 7 & 7.69 & $(3.15-15.21)$ \\
\hline Total & 670 & 16 & 2.39 & $(1.37-3.85)$ & 18 & 2.69 & $(1.60-4.21)$ & 68 & 10.15 & (7.97-12.69) \\
\hline
\end{tabular}




\section{Discussion}

I. ricinus ticks are widely distributed in moderate climatic regions of Europe in both natural and urban habitats. The occurrence and recent expansion of ticks into new areas are limited by temperature and saturation deficit $[5,7,38-40]$. The abundance of ticks in our sites correlated to the humidity and temperature. Neither saturation deficit nor vapour pressure deficit was significant. This might be due to the differences between the microclimatic conditions at our sites and data obtained from the meteorological stations as previously observed [8]. The seasonal activity of ticks can be unimodal with one maximum peak usually in late spring or early summer or bimodal with maximum peaks in spring or summer $[7,40]$. We have observed unimodal patterns for all of our sites. The tick activity in northeastern sites had a maximum peak in May, one month later than for southeastern sites. This correlates with the lower temperature increase in the north as one of the significant environmental factors affecting the tick abundance observed in our models. In neighbouring Hungary, Egyed et al. [40] reported bimodal activity for all their sites. In the statistical model our tick sites grouped into three "site groups"- A, B, C that represented the sites with the similar tick abundance and seasonal activities. Tick group "A" had the highest abundance of ticks and only one site belonged to this group - a dense suburban forest with shrubby vegetation in southeastern Slovakia. Group "B" consisted of sites represented by urban parks in southeastern Slovakia where the vegetation was more fragmented and forested sites from the northeastern Slovakia. Third group "C" grouped together sites with the least favourable conditions for tick abundace maintained urban park with large open spaces in southeastern Slovakia and dry suburban and urban forest in the northeast. Grouping of sites into three categories according to tick abundance showed that even small differences in the latitude (southern site vs. northern sites) with the lower daily mean temperature (Figure 1) can affect the tick abundance. Generally, less ticks were found in northeastern Slovakia in appropriate tick habitats as opposed to south.

Interestingly, the number of Lyme borreliosis cases per 100000 inhabitants were higher for the Bardejov region in northeastern Slovakia than for Košice in southeastern Slovakia. This is probably due to larger rural areas and different outdoor human behaviour patterns in the district of Bardejov, even though Košice is the second largest city in Slovakia. The link between human activities and incidence of tick-borne diseases has already been highlighted in previous studies $[41,42]$. Positive correlation between the abundance of ticks and seroprevalence against borrelia and TBE was observed among farmers in neighbouring Poland [43].
Questing ticks in our study were infected with all tested zoonotic bacteria with the dominance of $B$. burgdorferi s.l. as it was detected in 10.15\% (CI: 7.9512.69) of ticks. This is in agreement with the data from Eastern Slovakia obtained by Lenčáková et al. [44] where $11 \%$ of ticks were Borrelia positive. Similar infectious rates were detected in I. ricinus ticks from Estonia [45]. Prevalence of Borrelia in neighbouring countries in Hungary [40] and Poland [43] was slightly lower. In our dataset, the highest infection rate $(18 \%)$ was detected in a suburban forest in Košice, southeastern Slovakia, where the highest abundance of ticks was also recorded. Moreover, at this locality the highest diversity of Borrelia species was observed; probably due to a higher availability of hosts than in urban parks within the area. In the European countries, the infection rate of $A$. phagocytophilum infection in ticks is generally low. The results from the study in 11 sites in Switzerland showed 1.5\% infection rate and patchy distribution [20]. We obtained similar results with $2.69 \%$ (CI: $1.6-4.2 \%$ ) infection rates and it was detected at four out of ten sites. In contrast to Norway, at the areas with the higher density of the red deer, the prevalence of A. phagocytophilum was more consistent and higher (8.8\%) [46]. N. mikurensis, the recently emerging pathogen, was detected in $2.23 \%$ (CI:1.37-3.85\%) of ticks. Its distribution was, however, more homogenous than that for A. phagocytophilum, as it was detected in all northeastern sites in Bardejov. Recent studies show that N. mikurensis is common and frequently infects $I$. ricinus that is widely distributed in Europe [20,21].

\section{Conclusions}

Our data indicate that the risk of infection with tickborne pathogens in Eastern Slovakia is common since $15.2 \%$ of ticks were infected with at least with one of the tested microorganism. Even though the abundance of ticks was affected by the microclimatic conditions and the prevalence of pathogens differed between the habitats, the infection risk for humans is also affected by human activities leading to an increased contact with infected ticks.

\section{Competing interests}

The authors declare that they have no competing interests.

\section{Authors' contributions}

LP and MD drafted the manuscript. LP designed all statistical models and performed the statistical analyses. LP, MD, IH, BV and MS collected ticks, isolated DNA from ticks and performed molecular detection of pathogens. $\mathrm{MD}$ and $\mathrm{BP}$ designed the study. $\mathrm{HH}$ collected meteorological data. All authors have read and agreed with the content of the manuscript.

\section{Acknowledgements}

We thank Slavka Barláková for the English editing of the manuscript, Viktória Dandárová and Lucia Bajáčková for their help with collecting ticks. The study was supported by the projects VEGA 2/0055/11, VEGA 2/0137/10, by the Slovak Research and Development Agency under contract No. APW - 
0267-10. This contribution is partially the result of the project implementation: Development of the diagnostic methods for the detection of tickborne pathogens and the techniques for the preparation of the vaccine development (code ITMS: 26240220044), supported by the Research \& Development Operational Programme funded by the ERDF.

\section{Author details}

${ }^{1}$ Institute of Parasitology SAS, Košice, Hlinkova 3040 01, Slovakia. ${ }^{2}$ Institute of Zoology SAS, Bratislava, Dúbravská cesta 9845 06, Slovakia. ${ }^{3}$ Slovak Hydrometeorogical Institute, Košice, Dumbierska 26041 17, Slovakia.

Received: 17 April 2013 Accepted: 14 August 2013

Published: 16 August 2013

\section{References}

1. Lukáň M, Bullová E, Petkko B: Climate warming and tick-borne encephalitis, Slovakia. Emerg Infect Dis 2010, 16:524-526.

2. Bullová E, Lukáň M, Stanko M, Petłko B: Spatial distribution of Dermacentor reticulatus tick in Slovakia in the beginning of the 21st century. Vet Parasitol 2009, 165:357-360.

3. Materna J, Daniel M, Danielová V: Altitudinal distribution limit of the tick Ixodes ricinus shifted considerably towards higher altitudes in central Europe: results of three years monitoring in the Krkonose Mts. (Czech Republic). Cent Eur J Public Health 2005, 13:24-28.

4. Jaenson TGT, Jaenson DGE, Eisen L, Petersson E, Lindgren E: Changes in the geographical distribution and abundance of the tick Ixodes ricinus during the past 30 years in Sweden. Parasit Vectors 2012, 5:1-15.

5. Medlock JM, Hansford KM, Bormane A, Derdakova M, Estrada-Peña A, George JC, Golovljova I, Jaenson TG, Jensen JK, Jensen PM, Kazimirova M Oteo JA, Papa A, Pfister K, Plantard O, Randolph SE, Rizzoli A, Santos-Silva MM, Sprong H, Vial L, Hendrickx G, Zeller H, Van Bortel W: Driving forces for changes in geographical distribution of Ixodes ricinus ticks in Europe. Parasit Vectors 2013, 6:1-11.

6. Randolph SE, Storey K: Impact of microclimate on immature tick-rodent host interactions (Acari: Ixodidae): implications for parasite transmission. J Med Entomol 1999, 36:741-748.

7. Tagliapietra V, Rosa R, Arnoldi D, Cagnacci F, Capelli G, Montarsi F, Hauffe HC, Rizzoli A: Saturation deficit and deer density affect questing activity and local abundance of Ixodes ricinus (Acari, Ixodidae) in Italy. Vet Parasitol 2011, 183:114-124.

8. Li S, Heyman P, Cochez C, Simons L, Vanwambeke SO: A multi-level analysis of the relationship between environmental factors and questing Ixodes ricinus dynamics in Belgium. Parasit Vectors 2012, 5:149.

9. Gern L: Borrelia burgdorferi sensu lato, the agent of lyme borreliosis: life in the wilds. Parasite 2008, 15:244-247.

10. Margos G, Vollmer SA, Ogden NH, Fish D: Population genetics, taxonomy, phylogeny and evolution of Borrelia burgdorferi sensu lato. Infect Genet Evol 2011, 11:1545-1563.

11. Van Dam AP, Kuiper H, Vos K, Widjojokusumo A, De Jongh BM, Spanjaard L, Ramselaar AC, Kramer MD, Dankert J: Different genospecies of Borrelia burgdorferi are associated with distinct clinical manifestations of Lyme borreliosis. Clin Infect Dis 1993, 17:708-717.

12. Bazovská S, Ďurovská J, Derdáková M, Taragel’ová V, Pancák J, Záborská M, Traubner P: The genospecies Borrelia burgdorferi s.l., isolated from ticks and from neurological patients with suspected Lyme borreliosis. Neuro Endocrinol Lett 2011, 32:491-495.

13. Hubálek Z: Epidemiology of Lyme Borreliosis. Curr Probl Dermatol 2009, 37:31-50.

14. Woldehivet Z: The natural history of Anaplasma phagocytophilum. Vet Parasitol 2010, 167:108-122

15. Doudier B, Olano J, Parola P, Brouqui P: Factors contributing to emergence of Ehrlichia and Anaplasma spp. as human pathogens. Vet Parasitol 2010, 167:149-154.

16. Nováková M, Víchová B, Majláthová V, Lesňáková A, Pochybová M, Pet'ko B: First case of human granulocytic anaplasmosis from Slovakia. Ann Agric Environ Med 2010, 17:173-175.

17. Derdáková M, Štefančíková A, Špitálska E, Taragel'ová V, Koštálová T, Hrklová G, Kybicová K, Schánilec P, Majláthová V, Várady M, Pettko B: Emergence and genetic variability of Anaplasma species in small ruminants and ticks from Central Europe. Vet Microbiol 2011, 153:293-298.
18. Schouls LM, Van de Pol I, Rijpkema SG, Schot CS: Detection and identification of Ehrlichia, Borrelia burgdorferi sensu lato, and Bartonella species in Dutch Ixodes ricinus ticks. J Clin Microbiol 1999, 37:2215-2222.

19. Špitálska E, Literak I, Sparagano OAE, Golovchenko M, Kocianova E: Ticks (Ixodidae) from passerine birds in the Carpathian region. Wien Klin Wochenschr 2006, 118:759-764

20. Lommano E, Bertaiola L, Dupasquier C, Gern L: Infections and coinfections of questing Ixodes ricinus ticks by emerging zoonotic pathogens in western Switzerland. App Environ Microbiol 2012, 78:4606-4612.

21. Jahfari S, Fonville M, Hengeveld P, Reusken C, Scholte EJ, Takken W, Heyman P, Medlock P, Heylen D, Kleve J, Sprong H: Prevalence of Neoehrlichia mikurensis in ticks and rodents from North-west Europe. Parasit Vectors 2012, 5:74

22. Kawahara M, Rikihisa Y, Isogai E, Takahashi M, Misumi H, Suto C, Shibata S, Zhang C, Tsuji M: Ultrastructure and phylogenetic analysis of 'Candidatus Neoehrlichia mikurensis' in the family Anaplasmataceae, isolated from wild rats and found in Ixodes ovatus ticks. Int I Syst Evol Microbiol 2004 54:1837-1843

23. Vayssier-Taussat M, Le Rhun D, Buffet JP, Maaoui N, Galan M, Guivier E, Charbonnel N, Cosson JF: Candidatus Neoehrlichia mikurensis in bank voles, France. Emerg Infect Dis 2012, 18:2063-2065.

24. Fehr JS, Bloemberg GV, Ritter C, Hombach M, Luscher TF, Weber R, Keller PM: Bacterial pathogen Candidatus Neoehrlichia mikurensis. Emerg Infect Dis 2010, 16:1127-1129.

25. Welinder-Olsson C, Kjellin E, Vaht K, Jacobsson S, Wennerås C: First case of human Neoehrlichia mikurensis infection in a febrile patient with chronic lymphocytic leukemia. J Clin Microbiol 2010, 48:1956-1959.

26. Von Loewenich FD, Geissdörfer W, Disqué C, Matten J, Schett G, Sakka SG, Bogdan C: Detection of Candidatus Neoehrlichia mikurensis in two patients with severe fibrile illnesses: evidence for a European sequence variant. J Clin Microbiol 2010, 48:2630-2635.

27. Pekova S, Vydra J, Kabickova H: Candidatus Neoehrlichia mikurensis infection identified in 2 hematooncologic patients: benefit of molecular techniques for rare pathogen detection. Diag Microbiol Infect Dis 2011, 69:266-270

28. Diniz PP, Schulz BS, Hartmann K, Breitschwerdt EB: Candidatus Neoehrlichia mikurensis infection in a dog from Germany. J Clin Microbiol 2011, 49:2059-2062.

29. Derdáková M, Halánová M, Stanko M, Štefančíková A, Čisláková L, Pet'ko B: Molecular evidence for Anaplasma phagocytophilum and Borrelia burgdorferi sensu lato in Ixodes ricinus ticks from eastern Slovakia. Ann Agric Environ Med 2003, 10:269-271.

30. Zuur AF, leno EN, Walker NJ, Saveliev AA, Smith G: Mixed effects models and extensions in ecology with R. New York: Springer; 2009

31. Epidemiological Information System. http://www.epis.sk.

32. R Core Team: A language and environment for statistical computing http://www.R-project.org

33. Pinheiro J, Bates D, DebRoy S, Sarkar D: The R development core team n/me: linear and nonlinear mixed effect models, R package version 3.1-108; 2013. http://www.R-project.org

34. Guy EC, Stanek G: Detection of Borrelia burgdorferi in patients with Lyme disease by the polymerase chain-reaction. J Clin Pathol 1991, 44:610-611.

35. Derdáková $M$, Beati $L$, Pet́ko $B$, Stanko M, Fish D: Genetic variability within Borrelia burgdorferi sensu lato genospecies established by PCR - singlestrand conformation polymorphism analysis of the rrfA - rrlB intergenic spacer in Ixodes ricinus ticks from the Czech Republic. App/ Environ Microbiol 2003, 69:509-516.

36. De La Fuente J, Massung RF, Wong SJ, Chu FK, Lutz H, Meli M, Von Loewenich FD, Grzeszczuk A, Torina A, Caracappa S, Mangold AJ, Naranjo V, Stuen S, Kocan KM: Sequence analysis of the msp4 gene of Anaplasma phagocytophilum strains. J Clin Microbiol 2005, 43:1309-1317.

37. Altschul SF, Madden TL, Schaffer AA, Zhang J, Zhang Z, Miller W, Lipman DJ: Gapped BLAST and PSIBLAST: a new generation of protein database search programs. Nucleic Acids Res 1997, 25:3389-3402.

38. Perez JL, Guigoz E, Rais O, Gern L: Influence of saturation deficit and temperature on Ixodes ricinus tick questing activity in a Lyme borreliosisendemic area (Switzerland). Parasitol Res 2000, 86:554-557.

39. Knap K, Durmiši E, Saksida A, Korva M, Petrovec M, Avšič-Županc T: Influence of climatic factors on dynamics of questing lxodes ricinus ticks in Slovenia. Vet Parasitol 2009, 164:275-281. 
40. Egyed L, Élö P, Sreter-Lancz Z, Szell Z, Balogh Z, Sréter T: Seasonal activity and tick-borne pathogen infection rates of Ixodes ricinus ticks in Hungary. Ticks Tick Borne Dis 2012, 3:90-94.

41. Randolph SE: Human activities predominate in determining changing incidence of tick-borne encephalitis in Europe. Euro Surveill 2010, 15:24-21.

42. Stefanoff P, Rosinska M, Samuels S, White DJ, Morse DL, Randolph SE: A national case control study identifies human socio-economic status and activities as risk factors for tick-borne encephalitis in Poland. PLoS One 2012, 7:e4551

43. Cisak E, Wójcik-Fatla A, Stojek NM, Chmielewska-Badora J, Zwoliński J, Buczek A, Dutkiewicz J: Prevalence of Borrelia burgdorferi genospecies in Ixodes ricinus ticks from Lublin region (Eastern Poland). Ann Agric Environ Med 2006, 13:301-306.

44. Lenčáková D, Hizo-Teufel C, Pet"ko B, Schulte-Spechtel U, Stanko M, Wilske B, Fingerle V: Prevalence of Borrelia burgdorferi s.l. OspA types in Ixodes ricinus ticks from selected localities in Slovakia and Poland. Int J Med Microbiol 2006, 40:108-118.

45. Geller J, Nazarova L, Katargina O, Golovljova I: Borrelia burgdorferi sensu lato prevalence in tick populations in Estonia. Parasit Vectors 2013, 6:202.

46. Mysterud A, Easterday WR, Qviller L, Viljugrein H, Ytrehus B: Spatial and seasonal variation in the prevalence of Anaplasma phagocytophilum and Borrelia burgdorferi sensu lato in questing Ixodes ricinus ticks in Norway. Parasit Vectors 2013, 6:187.

doi:10.1186/1756-3305-6-238

Cite this article as: Pangrácová et al:: Ixodes ricinus abundance and its

infection with the tick-borne pathogens in urban and suburban areas of Eastern Slovakia. Parasites \& Vectors 2013 6:238.

\section{Submit your next manuscript to BioMed Central and take full advantage of:}

- Convenient online submission

- Thorough peer review

- No space constraints or color figure charges

- Immediate publication on acceptance

- Inclusion in PubMed, CAS, Scopus and Google Scholar

- Research which is freely available for redistribution 